\title{
Artikkeli
}

\section{Talouden asiantuntijoiden uskottavuuden hierarkia suomalaisten talous- ja politiikan toimittajien silmin}

\begin{abstract}
Esimerkiksi pankeissa, taloudellisissa tutkimuslaitoksissa ja valtionhallinnossa työskentelevät talousasiantuntijat ovat journalistien taajaan käyttämiä lähteitä. Julkisuudessa esiintyvät asiantuntijat arvioivat tehtyjä talouspoliittisia päätöksiä ja talouspolitiikan liikkumatilaa. Analysoin tässä artikkelissa talous- ja politiikan toimittajille suunnatun kyselytutkimuksen $(\mathrm{N}=42)$ sekä 19 teemahaastattelun avulla, miten talouspolitiikkaa seuraavat suomalaiset toimittajat arvioivat erilaisissa instituutioissa työskentelevien talousasiantuntijoiden uskottavuutta ja miten talousasiantuntijan uskottavuus rakentuu toimittajien silmissä. Artikkeli nojaa journalismin tutkimuksesta tuttuun uskottavuuden hierarkian käsitteeseen. Uskottavuuden hierarkian huipulla ovat tärkeimmät poliittiset vallankäyttäjät ja puolueettomiksi mielletyt asiantuntijat, kun taas poliittisesti marginaalisiksi koetut toimijat samoin kuin puolueellisiksi mielletyt asiantuntijat ovat alempana hierarkiassa. Esitän artikkelissa, että paikka talouden asiantuntijoiden uskottavuuden hierarkiassa määräytyy ennen kaikkea asiantuntijan institutionaalisen taustan mukaan. Suomen Pankin ja valtiovarainministeriön sekä Elinkeinoelämän tutkimuslaitoksen ja Palkansaajien tutkimuslaitoksen kaltaisten instituutioiden asiantuntijoita pidetään erityisen uskottavina, kun taas journalistien suhtautuminen pankkien talouspoliittiseen asiantuntemukseen on epäilevämpää. Vaikka valtionhallinnossa ja tutkimuslaitoksissa työskenteleviä asiantuntijoita pidetään yleisesti uskottavampina kuin pankkien asiantuntijoita, toimittajat suhtautuvat kriittisesti ajatukseen talouden asiantuntijatiedon puolueettomuudesta ja epäpoliittisuudesta.
\end{abstract}

AVAINSANAT: Talouspolitiikka, talousasiantuntijuus, asiantuntijuus, talousjournalismi, uskottavuuden hierarkia, uskottavuus

ournalismi kertoo faktoja taloustilanteesta ja koostaa yhteistä talouspoliittista tilannekuvaa (Berry 2019, 95-116). Niin kansalaiset kuin taloudellinen ja poliittinen päätöksentekoeliittikin seuraavat talouspolitiikkaa journalismin avulla (Ojala 2017; Philo 1995). Toimittajat välittävät tärkeää markkina- ja talousdataa myös yrityksille (Hurmeranta 2009, 
13-14), ja journalistiset esitykset talouspolitiikasta vaikuttavat kansalaisten arvioihin puolueiden ja poliittisten päättäjien talouspoliittisesta osaamisesta (Sanders ja Gavin 2004). Journalismia voi tarkastella myös kenttänä, jolla käydään tulkinnallista kamppailua esimerkiksi talouskriisien syistä ja kriisien edellyttämistä talouspoliittista ratkaisuista (Doudaki, Boubouka ja Tzalavras 2019; 350; Mylonas 2014, 308; Tracy 2012, 515-516).

Journalistit nojaavat asiantuntijoiden apuun tehdessään uutisia ja analyyseja talouspolitiikasta. Talousasiantuntijat, jotka työskentelevät usein esimerkiksi pankeissa, tutkimuslaitoksissa, yliopistoissa, työmarkkinaorganisaatiossa ja valtionhallinnossa, ovat talouspolitiikkaa käsittelevän journalismin ahkerasti hyödyntämiä lähteitä ja haastateltavia (Basu 2019, 326; Harjuniemi, Herkman ja Ojala 2015, 12; Simola ja Reunanen 2010, 140-145). Journalistien käyttämät talousasiantuntijat paitsi tulkitsevat ja avaavat talouspoliittisia ilmiöitä myös perustelevat erilaisten talouspoliittisten päätösten tarpeellisuutta (Cawley 2016; Berry 2016; Chadwick ym. 2020, 905-911; Vaara 2014, 508-509).

Journalismin tutkimuksessa on alettu pohtia journalismin ja talousasiantuntijoiden arvovallan ja uskottavuuden välistä suhdetta. Chadwick ja kumppanit (2020) kiinnittävät huomiota siihen, miten journalismi hyödyntää arvovaltaisimpia talousasiantuntijoita arvioidakseen poliitikkojen talouspoliittisia päätöksiä kriittisesti. Isossa-Britanniassa toimivien taloudellisten tutkimuslaitosten medianäkyvyyttä tutkinut Walsh (2021) arvioi samaan sävyyn, että journalismissa talouden asiantuntijoiden kyky arvioida talouspolitiikkaa kumpuaa asiantuntijalaitosten oletetusta puolueettomuudesta tai itsenäisyydestä.

Syvennän tässä artikkelissa journalismin ja talousasiantuntijuuden tutkimusta analysoimalla, miten talouspolitiikkaa käsittelevät suomalaiset toimittajat arvioivat erilaisten talouden asiantuntijalähteiden uskottavuutta ja millainen on suomalaisten talouden asiantuntijoiden uskottavuuden hierarkia (Becker 1967, 241). Tarkastelen, miten talousasiantuntijoiden institutionaalinen tausta vaikuttaa toimittajien arvioihin asiantuntijan uskottavuudesta ja miten toimittaja tunnistaa uskottavan talouden asiantuntijan. Artikkelin aineistona toimivat 19 toimittajan kanssa vuonna 2020 tehdyt teemahaastattelut sekä suomalaisille talouden ja politiikan toimittajille lähetetty kyselytutkimus, johon vastasi loppuvuodesta 2019 sekä vuoden 2020 ensimmäisellä puoliskolla 42 toimittajaa.

Teoreettisesti artikkeli nojaa journalismin tutkimuksessa käytettyyn uskottavuuden hierarkian (hierarchy of credibility) käsitteeseen (esim. Dimitrova ja Strömbäck 2009, 87; Hall ym. 1978, 58). Käsitteen taustalla on ajatus siitä, että ammattinsa normeihin sitoutuneen journalistin silmissä poliittiset toimijat ja asiantuntijat asettuvat hierarkkiseen järjestykseen, jonka huipulla ovat keskeiset vallankäyttäjät sekä puolueetonta tietoa tuottavat asiantuntijat (Hall ym. 1978, 58: Manning 2001, 71). Journalismin välittämä ja rakentama poliittinen keskustelu kuvaakin usein erilaisten eliittiryhmien näkemyksiä sekä eliittien välisiä konflikteja (Bennett 1990; Hallin 1984).

Tarkastelen artikkelin aluksi journalismin ja talousasiantuntijuuden välistä suhdetta. Avaan sen jälkeen uskottavuuden hierarkian käsitettä ja pohdin, miten käsite auttaa ymmärtämään journalismin ja asiantuntijuuden välistä suhdetta. Esittelen lukijalle tutkimuksen empiirisen aineiston, minkä jälkeen siirryn tutkimuksen tulosten käsittelyyn. Hahmottelen ensin kyselytutkimuksen tulosten perusteella talouden asiantuntijoiden uskottavuuden hierarkian peruspiirteitä. Osoitan, että suomalaiset talous- ja politiikan toimittajat pitävät valtionhallinnossa ja tutkimuslaitoksissa työskenteleviä talousasiantuntijoita yleisesti ottaen 
asiantuntevampina kuin esimerkiksi pankeissa työskenteleviä asiantuntijoita. Syvennän sen jälkeen analyysia haastatteluaineiston avulla keskittyen siihen, miten toimittajat arvioivat kahden näkyvän taloudellisen tutkimuslaitoksen (Elinkeinoelämän tutkimuslaitoksen Etlan ja Palkansaajien tutkimuslaitoksen PT:n), valtiovarainministeriön ja Suomen Pankin sekä yksityisten pankkien uskottavuutta. Keskenään erilaisiin, suomalaisessa talouspoliittisessa keskustelussa runsaasti näkyvyyttä saaviin (Harjuniemi, Herkman ja Ojala 2015, 13; Harjuniemi ja Ampuja 2019, 456; Parviainen 2014; Railo ja Ruohonen 2016, 86-87; Simola ja Reunanen 2010, 131-132; Uusitalo 2011) asiantuntijaryhmiin keskittymällä tuen kyselytutkimuksen tuloksista kumpuavaa havaintoa, jonka mukaan institutionaalinen asema määrittää asiantuntijan paikan uskottavuuden hierarkiassa. Vaikka pankeissa työskentelevät asiantuntijat ovat markkinoita seuraavia ammattilaisia ja toimittajien näkökulmasta hyödyllisiä asiantuntijalähteitä (Harjuniemi 2020, 56-57), heidän uskottavuuttaan nakertaa journalismiin kuuluva epäily (Reich 2011, 19), siitä, että pankkiasiantuntijat pyrkivät esiintymisillään edistämään työnantajiensa asemaa. Toisaalta artikkelin tulokset kertovat, että kysymystä uskottavuudesta ei tule palauttaa yksioikoisen institutionaaliseksi kysymykseksi. Haastatellut toimittajat arvioivat talousasiantuntijoita myös oman kokemuksensa ja aiemman talouskeskustelun valossa. Lisäksi esimerkiksi asiantuntijan aiemmat mediaesiintymiset tukevat tämän asemaa uskottavana talouskeskustelijana.

Artikkelin lopuksi pohdin vielä asiantuntijuuden ja poliittisen vaikuttamisen välistä suhdetta (Simola ja Reunanen 2010, 147-148). Haastatteluaineistosta käy ilmi, että toimittajat suhtautuvat kriittisesti ajatukseen talousasiantuntijuuden täydellisestä puolueettomuudesta. Moni haastateltu toimittaja päinvastoin korostaa, että talouspolitiikan kysymyksissä asiantuntijatieto ja politiikka niveltyvät väistämättä yhteen eikä talouden asiantuntijuus ole koskaan täysin neutraalia (vrt. Doyle 2006, 443-444).

\section{Journalismi ja talousasiantuntijuus}

Riippumattomuuden ja objektiivisuuden kaltaiset arvot ovat journalismin ammatillisen ideologian ytimessä (Deuze 2005; 448; Pöyhtäri, Väliverronen ja Ahva 2016, 12). Journalismin asema vallanpitäjien vahtikoirana ja demokraattisen päätöksenteon tukipilarina nojaa ajatukseen journalismin tasapuolisuudesta ja faktaperusteisuudesta. Journalismi pyrkii tarjoamaan kansalaisille luotettavaa ja riippumatonta tietoa poliittisen päätöksenteon tueksi (McNair 2008, 238).

Jotta journalismi pystyisi tarjoamaan ihmisille luotettavia uutisia, analyyseja ja kommentteja, se tarvitsee tuekseen asiantuntijoita (Berkowitz 2008, 103). Asiantuntijat - henkilöt, jotka ovat pätevöityneet tietyn alan tuntijoiksi (Schudson 2006, 499) - tarjoavat näkemyksiä ja tietoa, joiden avulla journalismia tehdään. Lisäksi journalismi tarvitsee asiantuntijoita oman puolueettomuutensa takeeksi: journalistien on usein pidättäydyttävä henkilökohtaisista kannanotoista ja tukeuduttava asiantuntijoihin, jotka tuovat journalismiin riippumattomia faktoja ja mielipiteitä (Albæk 2011; Boyce 2006). Asiantuntijoiden käyttö onkin yksi journalismin keskeisistä käytännöistä (Albæk, Christiansen ja Togeby 2003).

Asiantuntijat ovat näkyvässä roolissa myös talouspolitiikkaa käsittelevässä journalismissa. Kun journalismi uutisoi hallituksen finanssipolitiikan suunnasta tai analysoi Euroo- 
pan keskuspankin EKP:n rahapolitiikkaa, se nojaa usein asiantuntijoihin. Maallistuneissa, moderneissa yhteiskunnissa, joissa tieteen arvovalta on suurta (Weingart 1999), julkinen keskustelu talouspolitiikan toivottavasta suunnasta niveltyy usein asiantuntijoiden mielipiteiden ympärille (Mylonas 2014, 314; Vaara 2014, 508-509).

Journalismin tutkijat ovat kiinnittäneet huomiota talousasiantuntijoiden julkiseen rooliin erityisesti finanssi- ja eurokriisin yhteydessä. Simolan ja Reunasen (2010, 137-140) analyysista käy ilmi, että pankki- ja finanssialan asiantuntijat samoin kuin yliopistojen ja tutkimuslaitosten ekonomistit olivat usein esillä finanssikriisiä käsitelleessä journalismissa. Harjuniemi ja Ampuja (2019, 457-459) kirjoittavat, että valtiovarainministeriön arvovaltainen näkemys kurinalaisen taloudenpidon tarpeellisuudesta vaikutti osaltaan siihen, että suomalainen talouskeskustelu siirtyi vuoden 2008 finanssikriisin jälkimainingeissa nopeasti talouskurin linjalle (ks. myös Railo ja Ruohonen 2016, 86-87). Toisaalta osa talousasiantuntijoista toi suomalaiseen eurokriisikeskusteluun vyönkiristyslinjaa haastaneita äänenpainoja (Harjuniemi, Herkman ja Ojala 2015, 16).

Finanssikriisiä käsitellyttä brittijournalismia tutkineen Berryn (2019, 150-151) mukaan journalistit kääntyivät kriisin käänteitä ymmärtääkseen usein Lontoon Cityn finanssikeskuksen analyytikkojen ja ekonomistien puoleen. Myös Cawley $(2014,660)$ kiinnittää huomiota finanssialaa edustavien asiantuntijoiden vahvaan julkiseen asemaan ja siihen, miten irlantilainen media nosti heidät talouskriisin arvovaltaisiksi analyytikoiksi. Suomalaisten talousasiantuntijoiden medianäkyvyyttä tutkineen Parviaisen (2014) mukaan Helsingin Sanomat ja Yleisradio tukeutuivat eurokriisiä käsitellessään ensisijaisesti pankkien palveluksessa oleviin ekonomisteihin.

Jacobsson (2018) puolestaan vertailee ruotsalaista teollisuutta 1970-luvulla koetelleen talouskriisin journalistista käsittelyä 2010-luvun talousjournalismiin ja väittää, että markkinoiden liikkeitä ja vaatimuksia tulkitsevat talousasiantuntijat ovat vahvistaneet otettaan järjestäytyneen työväen esittämien näkökulmien kustannuksella. Samansuuntaista kritiikkiä yksipuolisuudesta esittää brittimediaa analysoinut Wren-Lewis (2018), joka pohtii, että laajalti kritisoidun ja kiistellyn vyönkiristyspolitiikan (ks. Blyth 2015) julkinen valta-asema on nojannut osin siihen, että journalistit sivuuttivat finanssikriisin aikana yliopistoekonomistit ja keskittyivät kuuntelemaan pankkien ja finanssilaitosten asiantuntijoita. Tällaista kehitystä ovat osaltaan ruokkineet myös läntisten talouksien rakennemuutokset: kun taloudellisen toimeliaisuuden ydin on siirtynyt valmistavasta teollisuudesta palveluihin ja rahoitukseen, taloutta ja talouspolitiikkaa käsittelevän journalismin painopiste on osin valunut perinteisistä työmarkkinakysymyksistä muun muassa rahoitusmarkkinoiden tarkasteluun (Davis 2018). Markkinoiden avautuminen ja pääomien entistä vapaampi liikkuminen ovat kasvattaneet myös journalismin tarvetta tukeutua markkinoiden liikkeitä tulkitseviin asiantuntijoihin (Pajari 2003, 183-184).

Journalismin tutkijat ovat siis analysoineet erilaisten asiantuntijoiden julkista näkyvyyttä laajalti. Tässä artikkelissa tarkastelen kuitenkin sitä, miten taloutta ja politiikkaa työkseen seuraavat toimittajat arvioivat erilaisten talousasiantuntijoiden uskottavuutta ja miten näkemys uskottavasta talouden asiantuntijasta rakentuu. Teema on merkittävä niin talouskeskustelun dynamiikan ymmärtämisen kuin monipuolisen talouspoliittisen keskustelunkin kannalta. Uskottaviksi mielletyt asiantuntijat saattavat toimia mediajulkisuudessa ikään kuin talouspolitiikan tuomareina (Chadwick ym. 2020). Journalistit saattavat suhtau- 
tua epäilevämmin talousasiantuntijoihin, joita ei pidetä uskottavina ja joiden ei koeta edustavan taloustieteellistä valtavirtaa (ks. Pedroso Neto ja Undurraga 2018, 2250-2253). Tässä artikkelissa lähestyn kysymystä journalismin ja asiantuntijan arvovallan välisestä suhteesta uskottavuuden hierarkian käsitteen avulla.

\section{Journalismi ja uskottavuuden hierarkia}

Uutistyön päivittäisessä paineessa toimivien journalistien on pystyttävä arvioimaan uutislähteidensä uskottavuutta ja painoarvoa rutiininomaisesti. Journalismin tutkijat ovat esittänet, että erilaiset lähteet asettuvat käytännön journalistisessa työssä uskottavuuden hierarkialle (hierarchy of credibility) (Becker 1967, 241). Kyse on järjestyksestä, jonka huipulla olevat lähteet ovat journalismin agendan ensisijaisia määrittelijöitä (Hall ym. 1978, 58). Uskottavuuden hierarkian huipulla ovat poliittisesti ja taloudellisesti vaikutusvaltaiset toimijat sekä puolueetonta tietoa tuottavat asiantuntijat, kun marginaalisempien poliittisten toimijoiden sekä puolueellisiksi miellettävien asiantuntijoiden on katsottu olevan alempana arvojärjestyksessä (Hall ym. 1978, 58; Laursen ja Trapp 2019, 3-5).

Journalismin tutkimuksessa on huomattu, että lähteiden asema uskottavuuden hierarkiassa määräytyy ensinnäkin lähteen vaikutusvallan mukaan (Volkmer ja Firdaus 2012, 109111). Journalistit seuraavat rutiininomaisesti demokraattisesti valittuja päättäjiä sekä erilaisia poliittisen ja taloudellisen vallan keskuksia: hallitusta, eduskuntalaitosta, ministeriöitä sekä esimerkiksi voimakkaita työmarkkinajärjestöjä ja yrityksiä (Hall ym. 1978, 58).

Toiseksi uskottavuuden hierarkian ylätasolla ovat asiantuntijalähteet, joiden painoarvo perustuu kykyyn tehdä todellisuudesta objektiivisia arvioita (Hall ym. 1978, 58). Uskottavan asiantuntijan todellisuudesta esittämät näkemykset perustuvat tieteellisin menetelmin hankittuun tietoon. Uskottava asiantuntija pystyy puhumaan arvovapaaksi mielletyn, omien ammattikäytäntöjensä mukaan toimivan tiedeyhteisön äänellä eikä ole minkään aatteen tai taustaintressin edustaja. (Laursen ja Trapp, 2019, 4-5.) Uskottavuuden takeena toimii ennen kaikkea asiantuntijan institutionaalinen tausta. Kaikkein uskottavimpia asiantuntijoita ovat puolueettomina pidetyt, esimerkiksi yliopistoissa tai tutkimuslaitoksissa työskentelevät asiantuntijat, kun taas journalistit suhtautuvat epäilevämmin asiantuntijoihin, joiden voi arvioida edustavan jotakin aatetta tai taloudellista tai poliittista eturyhmää (Deacon ja Golding 1994, 15; Hansen 1994, 119; Manning 2001, 158; Miller ja Williams 1998, 126).

On tietysti huomattava, että asiantuntijoiden journalistista käyttöä ei sanele yksin asiantuntijan institutionaalinen asema tai journalistin arvio asiantuntijan uskottavuudesta. Journalismissa hyödynnetään usein asiantuntijoita, joiden taustayhteisöillä on poliittisia ja taloudellisia intressejä. Asiantuntija saattaa olla journalistille hyödyllinen esimerkiksi käsiteltävänä olevan asian käytännön tuntijana, ammattilaisena, joka tuo aiheeseen sisäpiirin näkökulman (Steele 1995). Usein asiantuntijoita on kuultava myös poliittisen tasapainon nimissä: tiettyä aatesuuntaa tai näkökulmaa edustavan asiantuntijan näkemystä on tasapainotettava toisen asiantuntijan kommenteilla (Boyce 2006, 890). Asiantuntijan journalistiseen käyttöön voivat vaikuttaa myös hyvin käytännölliset syyt, kuten asiantuntijan tavoitettavuus tai se, että asiantuntija on jo entuudestaan tuttu julkisuudesta (Harjuniemi 2020, 44). 
Tässä artikkelissa hyödynnän uskottavuuden hierarkian käsitettä analysoidakseni, miten toimittajat arvioivat erilaisten talouden asiantuntijaryhmien uskottavuutta ja miten asiantuntijan uskottavuus rakentuu toimittajan silmissä. Kysymys siitä, miten journalistit arvioivat erilaisia talouden asiantuntijoita ja näiden uskottavuutta, on merkittävä. Moderneissa yhteiskunnissa päätöksentekoa on pystyttävä perustelemaan tieteen auktoriteetilla (Weingart 1999; Weible 2008). Talouden asiantuntijoita on syytä pitää erityisen vaikutusvaltaisina toimijoina, joiden näkemykset vaikuttavat muiden muassa poliitikkojen ja puolueiden toimintaan (Earle, Moran ja Ward-Perkins 2017; Mudge 2018).

\section{Tutkimuksen aineisto}

Tarkastelen suomalaisen talousasiantuntijuuden uskottavuuden hierarkiaa kyselytutkimuksen ja 19 teemahaastattelun avulla. Keräsin aineiston osana tutkimushanketta, jossa tutkittiin suomalaisten talous- ja politiikan journalistien käsityksiä muun muassa talouspolitiikkaa käsittelevän journalismin tehtävistä sekä erilaisten talouskeskustelijoiden asiantuntemuksesta medianäkyvyydestä (ks. Harjuniemi 2020). Talouspolitiikkaa työssään seuraavien ja käsittelevien toimittajien tavoittamiseksi kyselytutkimus lähetettiin joulukuussa 2019 Taloustoimittajat ry:n ja Politiikan toimittajat ry:n edustajille. Järjestöjen edustajat lähettivät kyselyn sekä sen oheen kirjoittamani saatteen edelleen jäsenilleen. Jäseniä muistutettiin kyselystä useaan otteeseen kevään 2020 aikana.

Taloustoimittajat ry ja Politiikan toimittajat ry ovat toimittajayhdistyksiä, jotka kokoavat yhteen päätoimisesti talouden ja politiikan parissa työskenteleviä toimittajia. Politiikan toimittajat ry:Ilä on noin 150 jäsentä (Politiikan toimittajat 2020). Taloustoimittajat ry:hyn puolestaan kuuluu noin 300 jäsentä (Taloustoimittajat 2020). Aktiivijäseniä, joihin ei lueta yhdistyksen kunniajäseniä tai eläkeläisiä, yhdistyksellä on tosin hieman vähemmän, vuoden 2017 lopulla noin 250 (Yrjänä 2018, 357). Tavoittaakseni järjestöihin kuulumattomia mutta niin ikään talouspolitiikkaa työssään käsitteleviä toimittajia lähetin kyselyn vielä keväällä 2020 erikseen noin 50 toimittajille. Tavoittelin toimittajia etsimällä merkittävimpien suomalaisten medioiden sivuilta tietoa toimittajista, jotka käsittelevät taloutta tai politiikkaa.

Kesään 2020 mennessä sain kyselyyn 42 vastausta. Vastaajista 23 oli miehiä ja 17 naisia, ja kaksi vastaajaa jätti sukupuolensa ilmoittamatta tai määritteli sen toisin. Liki puolet vastaajista oli yli 55-vuotiaita, ja runsaat 60 prosenttia vastaajista kertoi, että heillä on journalistista työkokemusta yli 20 vuotta. Noin 80 prosentilla vastaajista on vähintään alempi korkeakoulututkinto yliopistosta. Yliopistotutkinnot olivat useimmin valtio- tai yhteiskuntatieteellisestä tiedekunnasta. Enemmistö vastaajista oli opiskellut jonkin verran kauppatai taloustieteitä. Taloustieteen sivuaineopinnot yliopistossa olivat kauppa- tai taloustieteellisen koulutuksen yleisin muoto. ${ }^{1}$

Pienestä koostaan huolimatta vastaajajoukko vastaa profiililtaan melko hyvin suomalaisia taloustoimittajia (ks. Lindén 2012, 209-210). Suuri osa kyselyyn vastanneista toimittajista ilmoitti tiedotusvälineensä tyypiksi valtakunnallisen sanomalehden tai Yleisradion. Vastaajien joukossa oli lisäksi toimittajia muun muassa talousasioihin keskittyvistä lehdistä, iltapäivälehdistä, maakunnallisista sanomalehdistä sekä uutistoimistoista (ks. kuvio 1). 
Kuvio 1. Vastaajat tiedotusvälineidensä tyypin mukaan.

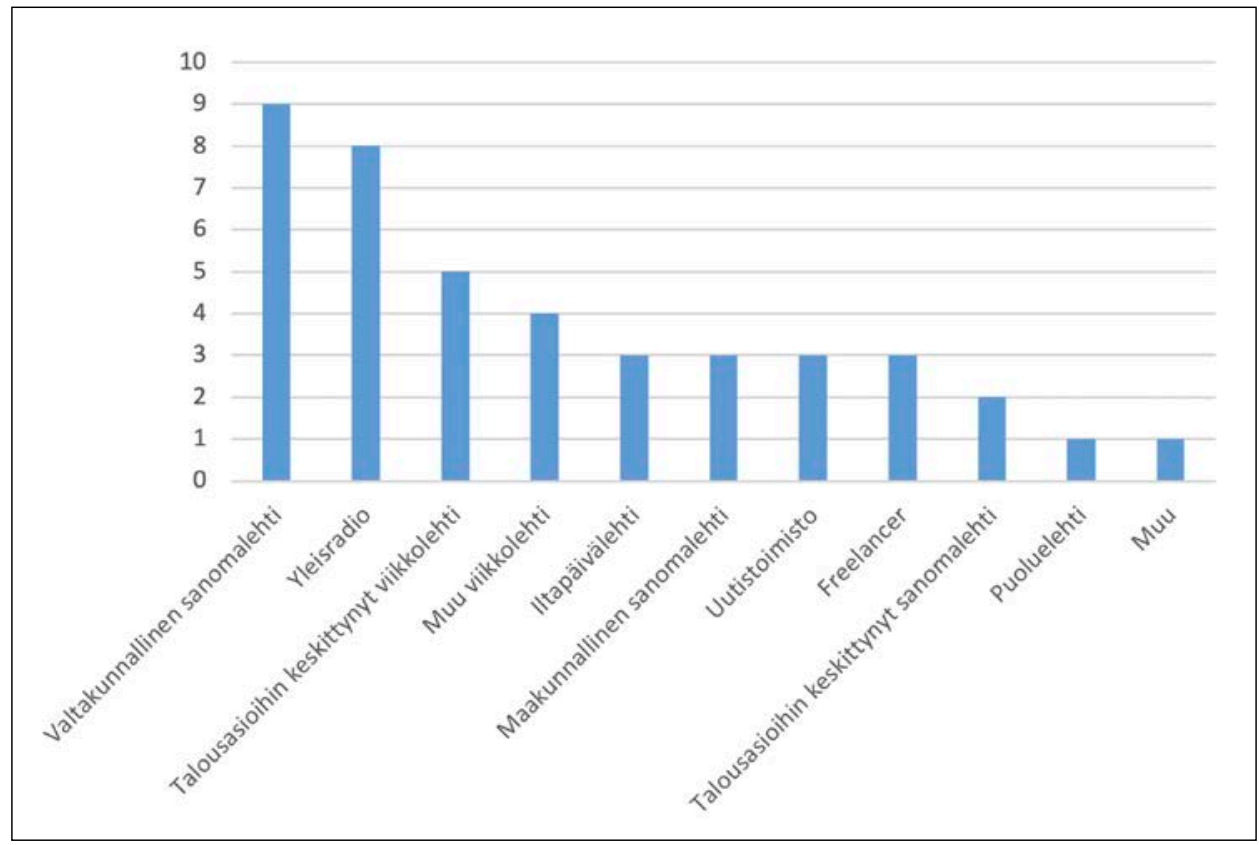

Vastaajien pienen lukumäärän vuoksi aineistoa oli tärkeä täydentää teemahaastatteluin. Haastattelin kevään ja alkukesän 2020 aikana 19:ää suomalaista talous- ja politiikan toimittajaa. Toimittajat päätyivät haastateltaviksi kolmea eri reittiä pitkin. Ensinnäkin toimittajilla oli mahdollisuus ilmoittautua haastateltaviksi kyselytutkimuksen kautta. Toiseksi otin suoraan yhteyttä moniin suomalaisiin talous- ja politiikan toimittajiin ja kysyin, tulisivatko he haastateltaviksi. Kolmanneksi pyysin haastatteluiden yhteydessä toimittajia mainitsemaan kollegoitaan, joita voisi olla hedelmällistä haastatella. Haastatellut toimittajat työskentelivät pääosin suurissa suomalaisissa yleis- ja talousmedioissa (ks. taulukko 1).

Taulukko 1. Haastatellut toimittajat tiedotusvälineen tyypin mukaan.

\begin{tabular}{|l|l|}
\hline Tiedotusväline & Haastateltavien lukumäärä \\
\hline Helsingin Sanomat & 4 \\
\hline Yleisradio & 3 \\
\hline Talouselämä & 2 \\
\hline Kauppalehti & 2 \\
\hline Iltalehti & 1 \\
\hline Maakuntalehti & 1 \\
\hline Puoluelehti & 1 \\
\hline Ammattiliiton jäsenlehti & 1 \\
\hline Vapaa toimittaja & 2 \\
\hline Eläkkeellä & 1 \\
\hline Vaihtanut vastikään journalismin parista toiseen ammattiin & 1 \\
\hline
\end{tabular}


Haastattelut olivat teemahaastatteluja, jotka kestivät keskimäärin noin tunnin. Olin laatinut haastatteluita varten kysymysrungon tutkimushankkeen teemoista, mutta esitin haastateltaville tarkentavia kysymyksiä teemoista ja aiheista, jotka nousivat esille haastatteluiden aikana. Haastatteluiden teemat liittyivät tutkimushankkeen aiheisiin, eivätkä kaikki kysymykset käsitelleet talouspolitiikan asiantuntijoita. Kysymykset koskivat muun muassa talouspolitiikkaa käsittelevän journalismin tehtäviä, talouspolitiikan journalismin moniäänisyyttä sekä sosiaalisen median roolia talouspolitiikkaa seuraavan toimittajan työssä. Iso osa kysymyksistä liittyi kuitenkin suoraan tämän artikkelin aiheeseen eli talouspolitiikan asiantuntijoihin ja näiden uskottavuuteen. Kysyin toimittajilta näkemyksiä muun muassa uskottavan asiantuntijan tunnistamisesta sekä erilaisista talouden asiantuntijaorganisaatioista, kuten valtionhallinnon instituutioista, tutkimuslaitoksista ja yksityisistä pankeista. Toimittajilta kysyttiin lisäksi näkemyksiä siitä, missä määrin erilaisia instituutioita edustavat asiantuntijat voivat olla puolueettomia.

Iso osa haastatteluista ehdittiin tehdä kasvotusten keväällä 2020 ennen koronapandemian kiihtymistä Suomessa. Haastatteluita tehtiin niin toimituksissa kuin kahviloissakin. Muutama haastattelu tehtiin keväällä ja kesällä 2020 verkon välityksellä. Haastattelumateriaali litteroitiin ja koodattiin Atlas.ti-analyysiohjelmistolla. Aineiston koodaus oli sekä teoria- että aineistolähtöistä. Aineiston analyysissa käytetyt koodit pohjasivat siis osin asiantuntijuutta ja journalismia koskevaan tutkimuskirjallisuuteen, mutta aineistoa koodattiin myös haastatteluissa esiin tulleiden teemojen mukaan. Tekstissä viittaan haastateltuihin toimittajiin anonyymisti nimikkeillä Toimittaja 1 - Toimittaja 19.

\section{Tulokset}

Tarkastelen seuraavaksi analyysin tuloksia. Olen jakanut tulosten esittelyn kahteen osaan. Hahmottelen ensin kyselytutkimusaineistoon nojautuen talousasiantuntijuuden uskottavuuden hierarkian peruspiirteitä. Kyselytutkimukseen vastanneet toimittajat pitävät taloudellisia tutkimuslaitoksia ja valtionhallinnon instituutioita - Suomen Pankkia ja valtiovarainministeriötä - asiantuntevampina talouskeskustelijoina kuin esimerkiksi pankkeja ja työmarkkinajärjestöjä. Syvennän tämän jälkeen analyysia tarkastelemalla haastatteluaineiston avulla, miten toimittajat arvioivat kolmen julkisuudessa runsaasti näkyvyyttä saavan asiantuntijaryhmän - tutkimuslaitosten, valtionhallinnon instituutioiden ja yksityisten pankkien - uskottavuutta. Haastatteluaineiston mukaan toimittajat pitävät tutkimuslaitoksia ja valtionhallinnon instituutioita uskottavampina asiantuntijalähteinä kuin yksityisten pankkien asiantuntijoita, vaikka myös jälkimmäiset ovat taajaan käytettyjä asiantuntijalähteitä taloutta ja talouspolitiikkaa käsittelevässä journalismissa.

Pohdin vielä tulokset esiteltyäni kysymystä asiantuntijuuden rakentumisesta sekä puolueettoman asiantuntijatiedon ja poliittisen vaikuttamisen välisestä suhteesta (ks. Simola ja Reunanen 2010, 147-148). Tämän artikkelin tulokset tukevat oletusta, jonka mukaan uskottavan asiantuntijuuden ehtona on tietty institutionaalinen asema. Näkemyksiin talousasiantuntijan uskottavuudesta vaikuttavat kuitenkin myös asiantuntijan aiemmat esiintymiset julkisuudessa sekä toimittajan oma kokemus talouskeskustelusta. Uskottava asiantuntijuus ei siis rakennu yksin teknisin perustein. Lisäksi on syytä huomata, että kysymys asiantuntijan uskottavuudesta sekä asiantuntijuuden ja poliittisen vaikuttamisen välisestä suhteesta on monisyinen. Vaik- 
ka asiantuntijat asettuvat uskottavuuden hierarkialle institutionaalisen asemansa mukaan ja vaikka toimittajien voi arvioida pitävän joitakuita asiantuntijoita uskottavampina kuin toisia, toimittajat arvioivat, että talouspolitiikan kysymyksissä asiantuntijatieto ja politiikka nivoutuvat väistämättä yhteen (vrt. Doyle 2006, 443-444). Toimittajat arvostavat talousasiatuntijoita, mutta kyseenalaistavat ajatuksen asiantuntijuuden täydellisestä objektiivisuudesta.

\section{Uskottavuuden hierarkian peruspiirteet}

Erilaisten talousasiantuntijoiden asiantuntemusta arvioidessaan toimittajat kertovat pitävänsä erityisesti tutkimuslaitoksia ja valtionhallinnon instituutioita asiantuntevina talouspoliittisina keskustelijoina (ks. kuvio 2). Yli 60 prosenttia vastaajista on täysin samaa mieltä siitä, että Suomen Pankin näkemykset talouspolitiikasta ovat yleisesti ottaen asiantuntevia. Toimittajat arvostavat myös Valtion taloudellisen tutkimuskeskuksen VATTin, Elinkeinoelämän tutkimuslaitoksen Etlan, Palkansaajien tutkimuslaitoksen PT:n sekä valtiovarainministeriön asiantuntemusta. Toimittajat pitävät myös yliopistoissa työskenteleviä ekonomisteja asiantuntevina keskustelijoina. Yllä mainittujen organisaatioiden kohdalla yli 80 prosenttia vastaajista on vähintään jokseenkin samaa mieltä sen väitteen kanssa, että niiden esittämät näkemykset talouspolitiikasta ovat asiantuntevia.

Kuvio 2. Toimittajien näkemyksiä talouspoliittisen asiantuntijoiden ja keskustelijoiden asiantuntemuksesta.

\section{Seuraavien tahojen näkemykset talouspolitiikasta ovat mielestäni yleisesti ottaen asiantuntevia}

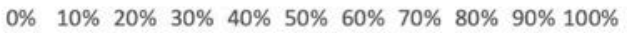

Valtion taloudellinen tutkimuskeskus VATT

Elinkeinoelämän tutkimuslaitos Etla

Suomen Pankki

Palkansaajien tutkimuslaitos PT

Valtiovarainministeriö

Yliopistoissa työskentelevät ekonomistit

Yksityiset pankit ja niiden edustajat

Työnantajien keskusjärjestöt ja liitot

Työntekijöiden keskusjärjestöt ja liitot

Elinkeinoelämän valtuuskunta EVA

Yritykset ja niiden johtohenkilöstö

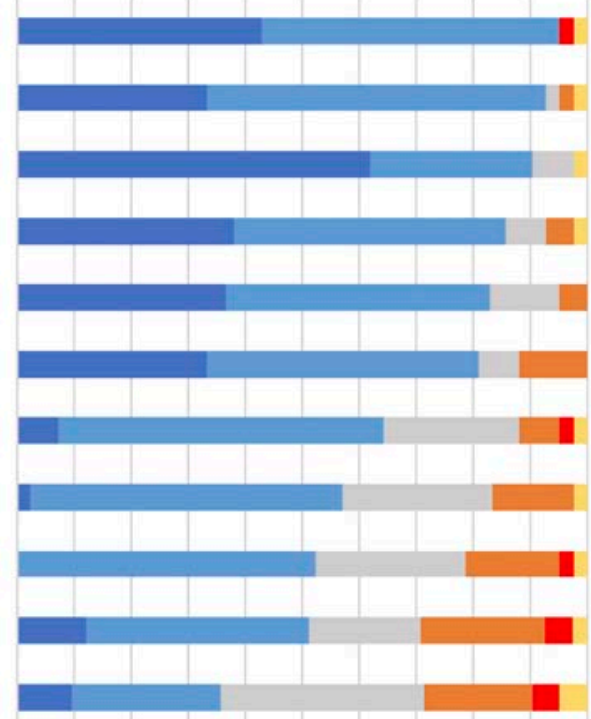

- Täysin samaa mieltä

= Jokseenkin eri mieltă

nokseenkin samaa mieltä - Täysin eri mieltä
Ei samaa eikä eri mieltä En osaa sanoa 
Tuloksista voi päätellä, että asiantuntijoiden arvostus heijastelee asiantuntijan institutionaalista asemaa (ks. Hansen 1994, 119). Suomen Pankki ja valtiovarainministeriö ovat historiallisesti olleet suomalaisen talouspolitiikan valmistelun keskiössä (Kantola ja Kananen 2013, 812; Pekkarinen 1989, 325), minkä lisäksi ne ovat olleet näkyviä ja vaikutusvaltaisia talouspoliittisia keskustelijoita (Pennanen ja Ristimäki 2003, 179; Railo ja Ruohonen 2016, 86-87). Myös taloustieteelliset tutkimuslaitokset, kuten Valtion taloudellinen tutkimuskeskus VATT, Elinkeinoelämän tutkimuslaitos Etla ja Palkansaajien tutkimuslaitos PT, ovat arvostettuja talouspoliittisia asiantuntijakeskustelijoita. Sekä Etla että PT ovat taloustieteellistä tutkimusta ja talousennusteita tekeviä tutkimuslaitoksia. Molemmilla on kuitenkin omat taustaintressinsä: Etla on osittain suomalaisen elinkeinoelämän ja PT osin ammattiyhdistysliikkeen rahoittama. Laitokset ovat siis paitsi tutkimusorganisaatioita myös poliittisia aloitteita ja ideoita tuottavia toimijoita. (Simola ja Reunanen 2010, 140.) Kysely osoittaa, että molemmat laitokset ovat taustakytköksistään huolimatta arvostettuja asiantuntijaorganisaatioita.

Kuten odottaa saattaa, vastaajat suhtautuvat pankkien ja työmarkkinaorganisaatioiden asiantuntemukseen kriittisemmin kuin tutkimuslaitosten ja julkishallinnon instituutioiden asiantuntemukseen. Vaikka yli 60 prosenttia vastaajista on vähintään samaa mieltä sen väitteen kanssa, että yksityisten pankkien näkemykset talouspolitiikasta ovat asiantuntevia, on täysin samaa mieltä olevien vastaajien osuus selvästi pienempi kuin arvostetuimpien organisaatioiden kohdalla. Sama pätee esimerkiksi työntekijä- ja työnantajapuolta edustavien organisaatioiden kohdalla.

Havainto on ymmärrettävä. Vaikka esimerkiksi pankit ovat tärkeitä julkisia keskustelijoita ja talouden asiantuntemuksen lähteitä (Harjuniemi, Herkman ja Ojala 2015, 12-13), toimittajat suhtautuvat niihin epäilevämmin kuin esimerkiksi tutkimuslaitoksiin. Havainto tukee näkemystä, jonka mukaan toimittajat suhtautuvat kriittisesti sellaisiin asiantuntijoihin, joiden voi epäillä edustavan jotakin poliittista tai taloudellista eturyhmää (vrt. Miller ja Williams 1998, 126). Tällaista olettamaa tukee sekin, että journalistit arvioivat Elinkeinoelämän valtuuskunnan Evan asiantuntemusta kriittisesti. Eva on markkinaliberaali ajatuspaja, joka tuottaa ja julkaisee selvityksiä, analyyseja ja pamfletteja (Eva 2020; Wuokko 2017).

Seuraavaksi analysoin toimittajien suhtautumista erilaisiin asiantuntijaryhmiin tarkemmin, kun lähestyn haastatteluaineiston avulla kysymystä valtionhallinnon instituutioiden (Suomen Pankin ja valtiovarainministeriön), tutkimuslaitosten (Etla ja PT) ja sekä yksityisten pankkien uskottavuudesta.

\section{Tutkimuslaitoksia ja valtionhallinnon instituutioita arvostetaan}

Haastatteluissa pyysin toimittajia arvioimaan Elinkeinoelämän tutkimuslaitosta Etlaa ja Palkansaajien tutkimuslaitosta talouspolitiikan asiantuntijalähteinä. Molemmat tutkimuslaitokset ovat näkyviä tahoja suomalaisessa talouspoliittisessa keskustelussa (Simola ja Reunanen 2010; Uusitalo 2011), minkä vuoksi on tärkeää analysoida, miten toimittajat arvioivat niiden uskottavuutta.

Haastateltavat mainitsevat moneen otteeseen, että toimittajien on oltava tietoisia molempien laitosten taustoista ja rahoittajista. Samalla toimittajat kuitenkin pitävät niitä taloustieteellistä tutkimusta tekevinä laitoksina, joissa työskentelevien tutkijoiden itsenäi- 
syyteen ja ammattimaisuuteen voi luottaa. Toimittajien arvioissa laitokset näyttäytyvätkin uskottavina asiantuntijakeskustelijoina. Haastateltu talouslehden toimittaja kertoo voivansa luottaa molempien laitosten "integriteettiin", vaikka korostaakin samalla sitä, että laitosten erilaiset taustat on pidettävä kirkkaina mielessä. Toinen haastateltu toimittaja pohtii samaan sävyyn (ks. sitaatti alla), että Etla ja PT ovat objektiivisempia kuin työmarkkinoiden keskusjärjestöt EK ja SAK, joiden näkemyksiin journalismi niin ikään usein tukeutuu.

Mun mielestä ne on vähän semmoisia, että kun halutaan vähän objektiivisempaa, niin sitten [päällikkö] sanoo, että no, tee tutkimuslaitoskierros [naurua]. Että jos ei ihan halua mennä sille linjalle, että nyt laitetaan vastakkain joku SAK ja EK, niin sitten tavallaan ajatellaan, että olisiko enemmänkin näkökulmaa jostakin tutkimuslaitoksista. Että kyllä mun mielestä ne näyttäytyy ehdottomasti enemmän objektiivisempina ja enemmän niin kuin juuri asiantuntijatahoina, semmoisina, joilla, vaikka niilläkin tietenkin on näkökulmansa, kaikilla on näkökulmansa, mutta tavallaan ei ole ehkä niin tavallaan voimakasta semmoista leimaa [...] (Toimittaja 8.)

Se, että laitokset koetaan ammattimaisiksi asiantuntijaorganisaatioiksi, vahvistaa niiden asemaa uskottavuuden hierarkiassa. Eräs toimittaja pohtii haastattelussa, että Etla on säilyttänyt, rahoituksestaan huolimatta, itsenäisyytensä. Osin tämän vuoksi Etlalla on "vahva ääni", jota on vaikea ohittaa journalismissa, journalisti miettii. Toinen toimittaja kertoo, että hän pohtii rutiininomaisesti asiantuntijoiden taustoja, jotka eivät kuitenkaan väistämättä heijastu asiantuntijoiden lausuntoihin. Hän miettiikin, että on vaikea arvioida, miten tutkimuslaitoksen rahoitus heijastuisi tutkijoiden puheenvuoroihin:

Kyllä mä koko ajan sitä vähän silleen pidän silmällä [taustoja]... Mutta sitten sekin on vaikeaa mun mielestä tehdä selvää eroa, että no mitä vaikka Etla, et onko se nyt sitten siellä selvästi elinkeinoelämän asialla. Tai Palkansaajien tutkimuskeskus [...]. (Toimittaja 3.)

Eräs toimittaja kertoo, että molempia laitoksia pidetään "aika luotettavina", ja pohtii samalla, että "terve epäily" siitä, ovatko laitokset rahoittajiensa asialla, kuuluu tietysti journalismiin. Toisaalta toinen haastateltu journalisti miettii, että laitoksia voidaan kritisoida jopa liiaksi niiden taustakytkösten vuoksi. Toimittajan mielestä molemmat laitokset ovat ennen kaikkea itsenäisiä tutkimusorganisaatioita:

Ei siinä, jos niiden kanssa puhuu, niin ei siinä tulee sellainen olo, että nämä puhuu jonkun äänellä tässä, vaan kyllä ne [...] ihan oikeita tutkijoita [on]. (Toimittaja 14.)

Journalismiin kuuluva epäily lähteen uskottavuutta ja motiiveja kohtaan (Reich 2011, 19) sävyttää paikoin journalistien arvioita tutkimuslaitoksista. Samalla molempien laitosten tutkijoita kuitenkin arvostetaan, eivätkä tutkimuslaitosten erilaiset lähtökohdat näyttäydy uskottavan asiantuntijatyön esteinä:

Mun mielestä huomaa, että heillä [tutkimuslaitoksilla] on tiettyä agendaa siellä tietysti, mutta kyllä mä molempia pidän lähtökohtaisesti uskottavina, ja molemmilla on hyviä tutkijoita. Suomessa on muutenkin näissä eri laitoksissa mun mielestä hyviä tutkijoita. (Toimittaja 12.) 
Tutkimuslaitosten tavoin myös valtiovarainministeriö ja Suomen Pankki näyttäytyvät toimittajien silmissä uskottavina talouden asiantuntijoina. Haastatellut toimittajat arvioivat useaan otteeseen, että aivan kuten tutkimuslaitoksiin myös virkamiehiin voi Suomessa laajalti luottaa. Yksi journalisti kertoo huomanneensa, että hän pitää valtiovarainministeriötä ja Suomen pankkia jopa "neutraalimpana kuin näitä Etlaa ja palkansaajia". Haastateltu vapaa arvioi Suomen Pankkia ja valtiovarainministeriö samaan tyyliin ja toteaa, että "molemmissa on tosi kovaa asiantuntijuutta, siis aivan niin kuin huippua".

Sekä valtiovarainministeriöllä että Suomen Pankilla on perinteisesti ollut vahva asema suomalaisen talouspolitiikan suunnittelussa ja valmistelussa. On arvioitu, että Suomessa talouspolitiikkaa on tehty Suomen Pankin ja valtiovarainministeriön askelmerkkien mukaan. (Kantola ja Kananen 2013, 812; Pekkarinen 1989, 325; Pekkarinen ja Heinonen 1998.) Merkittävinä ja vaikutusvaltaisina instituutioina Suomen Pankki ja valtiovarainministeriö ovat itseoikeutetusti korkealla talouden asiantuntijuuden uskottavuuden hierarkiassa. Molemmat instituutiot ovat arvokkaita tietolähteitä. Suomen Pankin ja valtiovarainministeriön kohdalla uskottavuutta tukeekin se, että ne tuottavat tärkeää ja luotettavaksi miellettyä taloustietoa. Eräs haastateltava miettii, että hallituksen budjettipolitiikasta kirjoitettaessa "faktatsekkaukset" on haettava valtiovarainministeriöstä. Toinen puolestaan pohtii, että esimerkiksi Euroopan talous- ja rahaliittoon liittyvissä kysymyksissä paras asiantuntijuus löytyy todennäköisesti Suomen Pankista. Sama toimittaja arvelee, että valtiovarainministeriön vahvaa asemaa talouspolitiikan julkisuudessa tukevat osittain uutistyön arkiset käytännöt ja ministeriön tukeva asema journalismin agendan määrittäjänä (vrt. Hall 1978, 57). Hän kertoo, että valtiovarainministeriön ennusteita ja laskelmia seurataan rutiininomaisesti:

Ja siinä mennään kyllä ehkä sitten semmoiseen tietynlaiseen uutiskoneistoasiaan myöskin. Et siellä on kalenterissa tiedossa päivämäärä monta viikkoa ennen, että tällöin tulevat rätingit, valtiovarainministeriöltä tulee tästä tai tästä esitys. Ja sitten sitä suunnitellaan, et kuka sen hoitaa [...]. Enemmän tai vähemmän kuitenkin aina se, joka siihen lähtee tekemään, niin se lähtee siihen kohtuullisen pienellä varoajalla. Että ei siinä mitään viikon valmistautumista ole, että pohditaanpa, mikä kulma tähän tällä kertaa otetaan, vaan sitten se tulee, et ai niin se onkin huomenna [...] mun pitääkin nyt ruveta katsomaan sitä. Että se tietysti johtaa herkästi siihen, että se menee niitten [...] ikään kuin niitten pelimerkkien mukaan, mitä sieltä sinä päivänä tulee. (Toimittaja 4.)

Valtiovarainministeriö ja Suomen Pankki ovat journalismin näkökulmasta tärkeitä tietolähteitä ja uskottavia asiantuntijaorganisaatioita. Samalla niiden vahvaa asemaa julkisuudessa pohditaan kriittisesti. Moni haastateltu toimittaja miettii, tulisiko journalistien haastaa ministeriön ja Suomen Pankin näkemyksiä ja auktoriteettia nykyistä aktiivisemmin. Toimittajat tunnistavat erityisesti valtiovarainministeriön vahvaksi talouspoliittiseksi toimijaksi, joka ajaa kurinalaisen talouspolitiikan linjaa:

[K]yllähän VM, se jollain tavalla liittyy ehkä siihen, että koska [...] se koetaan vallankäyttäjänä ja asiantuntijana ja semmoisena, että jos Suomessa menee huonosti, tai vaikka hyvinkin menisi tai ihan miten tahansa, [...] niin VM:stä tulee se viimeinen sana ikään kuin. (Toimittaja 19.) 
Journalismin näkökulmasta valtiovarainministeriö on kuitenkin niin merkittävä institutionaalinen vallankäyttäjä, että sille on pakko antaa tilaa. Eräs toimittaja kertoo, että hänen edustamansa lehti saa usein kritiikkiä siitä, että lehdessä kuunnellaan valtiovarainministeriötä herkällä korvalla. Hän kuitenkin arvioi, että poliitikot kuuntelevat ministeriön linjauksia tarkasti, minkä vuoksi myös journalistien on kerrottava ministeriön ajattelusta. Toinen toimittaja kertoo, että ministeriön "huippuvirkamiehillä" talouspoliittinen osaamistaso on eri luokkaa kuin jopa johtavilla politikoilla, minkä vuoksi ministeriön vahva rooli talouspolitiikan suunnittelussa on ymmärrettävää. Kolmas toimittaja arvioi, että ministeriötä on syytäkin seurata, sillä valtiontaloutta hoidetaan ministeriön antamien askelmerkkien mukaan:

Kyllä se saa aika paljon arvovaltaa ja saa paljon tilaa, ja se uutisoidaan heidän näkemyksensä. Ja tietysti pitääkin osittain siitä syystä, että se on kuitenkin pohjana valtiontaloudelle, että sieltä tulee ne raamit, mitä sitten toi ministeri noudattaa. Että siinä mielessä se on merkittävä taho. Ehkä voisi enemmänkin, ehkä pitäisi enemmän olla niin kuin niiden kriittistä arviointia [...]. (Toimittaja 13.)

\section{Toimittajien suhtautuminen pankkien asiantuntemukseen on epäilevämpää}

Pankkeja edustavat asiantuntijat eivät haastatteluiden perusteella näyttäydy yhtä uskottavina asiantuntijoina kuin esimerkiksi tutkimuslaitosten ekonomistit. Pankkien asiantuntijoiden kohdalla journalistit kiinnittävät enemmän huomiota asiantuntijoiden työnantajien - yksityisten pankkien - mahdollisiin intresseihin. Eräs toimittaja analysoi alla olevassa sitaatissa kysymystä siitä, miten toimittajien on suhtauduttava pankkien asiantuntijoiden taustoihin:

Nehän edustaa vahvasti elinkeinoelämää [...]. [T]ämmöinen [että] menisi kysymään niiltä, millaista talouspolitiikkaa tässä maassa pitäisi tehdä, niin kuin jotkut varmaan kysyy ja jotenkin aikaisemmin on kysynyt, musta se on väärä tapa kysyä sitä. Just niin kuin [Nordean entinen pääekonomisti ja sittemmin Elinkeinoelämän tutkimuslaitokseen Etlaan siirtynyt Aki] Kangasharju, jos muistelee sitä, kun se oli Nordeassa, niin siltä saatettiin kysyä ja se kovasti halusi kertoa kantansa monenlaisiin, just valtion velkaantumiseen [...]. Kannattaako sitä sitten ottaa kauhean vakavasti? Tai siis voihan hän olla oikeassakin, mutta se vain kuulostaa pahalta, jos se tulee niin kuin Nordeasta [...]. (Toimittaja 1.)

Eräs haastateltava arvioi haastattelussa kriittisesti, että pankkiekonomistit hallitsevat julkisuuden "ilmatilaa". Hän arvioi, että taloustoimittajat soittavat mieluusti muutamille tuntemilleen pankkien pääekonomisteille, jotka tarkkailevat asioita tietystä näkökulmasta. Samalla hän muistuttaa, että pankkien asiantuntijoihin saatetaan journalismissa tukeutua käytännön syistä:

Nää muutamat tyypit, ja se on siinä. Ikään kuin siinä olisi totuus, ikään kuin pankin pääekonomisti ei ajaisi mitään politiikkaa, vaan katsoo kylmiä numeroita, sehän on ihan täyttä paskaa. Totta kai ne katsoo pankin näkökulmasta numeroitakin, mutta, se on tietysti tavallaan helppoakin, jos sä johonkin uutisjuttuun tarvitset kommentin, niin sä tiedät, kuka osaa sen sanoa. On niin kuin tämmöinen valmis lausuntoautomaatti. (Toimittaja 5.) 
Vaikka toimittajat arvioivat pankkien uskottavuutta ja motiiveja kriittisemmin kuin tutkimuslaitosten ja valtionhallinnon instituutioiden, moni haastateltava sanoo, että pankkeja kuitenkin tarvitaan tiedon ja analyysien lähteinä. Pankkien asiantuntijat seuraavat markkinoita ja kansantalouden dataa reaaliaikaisesti ja ovat näin tärkeitä taloustiedon tuottajia. Yksi toimittaja miettii haastattelussa, että Nordean "massiivinen" koneisto tuottaa dataa ja analyyseja, joita journalismissa luonnollisesti hyödynnetään. Maakuntalehden toimittaja arvioi samaan sävyyn, että joitakin talouspolitiikan kysymyksiä käsiteltäessä pankkien asiantuntemukselle ei juuri ole vaihtoehtoja:

[T]ietyistä kansainvälisistä asioista melkein täytyy vuorenvarmasti soittaa - esimerkiksi valuuttakurssiasioista - Nordeaan, asianomaiselle ekonomistille, joka on perehtynyt niihin asioihin. (Toimittaja 18.)

Journalistien arvioita pankkien taloudellisesta asiantuntemuksesta luonnehtii kahtalainen sävy. Toisaalta pankkien kohdalla journalistien on oltava kriittisiä ja pidettävä mielessä pankkien mahdolliset motiivit. Toisaalta myös pankkien asiantuntemusta arvostetaan ja hyödynnetään. Pankkien asiantuntijoihin ei myöskään kannata suhtautua liian epäilevästi. Yksi haastateltava toimittaja kertoo, että taloustieteilijän asema "yksityisessä liikepankissa tai työmarkkinajärjestössä" on otettava huomioon, mutta liian kyyninen ei kannata olla. Jos kyse on "makrotalouden kysymyksistä", voi olla vaikea nähdä, miten pankin asiantuntijan julkisuudessa esittämät arviot voisivat vaikuttaa pankin tulokseen, toimittaja pohtii. Hän kuitenkin muistuttaa, että pankin asiantuntemuksen taustat on syytä tuoda esille vaikkapa asuntomarkkinoita käsiteltäessä:

[M]utta sitten vaikka kun [on] asuntoluototukseen erikoistunut pankki ja sen ekonomisti puhuu asuntomarkkinoista, niin kyllä siinä mun mielestä, se pitää miettiä tarkasti. Siis siinäkään ei pidä olla, että ei voida julkistaa näitä näkemyksiä, koska niillä voi olla hyvin tehtyä tutkimusta ja tosi hyviä näkemyksiä, mutta siinä mun mielestä jotenkin pitää ainakin tuoda selvästi lukijalle esiin, että tämä pankki on erikoistunut asuntoluototukseen ja saa niin kuin rahansa asunto[luottojen] myöntämisestä. (Toimittaja 14.)

\section{Talousasiantuntijoita arvostetaan, mutta asiantuntijuus ei ole} täysin puolueetonta

Haastattelumateriaali siis tukee kyselytutkimuksen tuloksista kumpuavaa havaintoa, jonka mukaan näkyvät suomalaiset talouden asiantuntijainstituutiot asettuvat journalistien silmissä hierarkkiseen järjestykseen. Odotetusti asiantuntijan uskottavuus mukailee tämän institutionaalista asemaa. Toimittajat pitävät taloustieteellisiä tutkimuslaitoksia ja valtionhallinnon instituutioita uskottavampina talouden asiantuntijoina kuin pankkien asiantuntijoita, joihin suhtaudutaan kriittisesti mutta joita pidetään silti hyödyllisinä ja ammattimaisina.

Journalisti tunnistaa pätevän ja uskottavan talouden asiantuntijan nimenomaan tämän taustainstituution avulla. Kysyttäessä, mistä toimittaja tunnistaa uskottavan talouden asiantuntijan, haastateltavat kertovat arvioivansa asiantuntijan titteliä ja sitä, 
missä tämä työskentelee. Näin toimittaja voi luottaa siihen, että asiantuntijan näkemykset pohjaavat tutkittuun tietoon:

[J]os siinä on taustalla meillä yliopistot tai tutkimuslaitokset, niin silloinhan se tuo uskottavuutta, että me tiedetään, että ei siellä kuka tahansa tutki tai kuka tahansa pääse tekemään. (Toimittaja 13.)

Asiantuntijan uskottavuuteen voivat toimittajan silmissä toisaalta vaikuttaa muutkin tekijät kuin pelkkä institutionaalinen asema. Ensinnäkin talouden asiantuntijan uskottavuutta lisää se, että tämä on ollut esillä mediassa aiemminkin. Tällöin toimittaja voi luottaa siihen, että kyseessä on laajalti tunnettu asiantuntija. Jos kyseessä on entuudestaan tuntematon nimi, on asiantuntijan taustoja tarkasteltava tarkemmin. Asiantuntijan uskottavuutta tukee siis paitsi institutionaalinen asema myös aiempien julkisten esiintymisten kasvattama henkilökohtainen "mediapääoma" (Davis ja Seymour 2010, 742-743). Taloutta seuraava freelance-toimittaja kertoo haastattelussa, että paras "luotettavuusmerkkihän" on, jos henkilö on mainittu Financial Timesissa tai Wall Street Journalissa. Heikompi tunnettuus saattaa jossain määrin heikentää esimerkiksi yliopistotutkijoiden asemaa. Haastateltu toimittaja pohtii yliopistotutkijoiden käytettävyyttä ja ottaa vertailukohdaksi elinkeinoelämän Etlan ja Palkansaajien tutkimuslaitoksen, joiden näkemyksiä risteyttämällä toimittaja pystyy rakentamaan tasapainoisen talousjutun:

[M]ä luulen, että yliopistoväki ehkä hiukan on jäänyt paitsioon [...]. Et yliopistoväkeä on haastateltu vähemmän viimeisten viiden, kymmenen vuoden aikana. Mulla ei oo tästä tietoo - tää on ihan puhdasta mututuntumaa - juuri sen takia, että ei väkeä enää oikein tunneta niin paljon. Ja sit laitoksista saa helpommin ikään kuin sitä, että jos halutaan joku, joka on palkansaajien ja sit joku elinkeinoelämän, niin heitä saa risteytettyä helposti. (Toimittaja 4.)

Käsitys asiantuntijan uskottavuudesta rakentuu ajan myötä, kun toimittaja oppii arvioimaan asiantuntijoiden näkemyksiä oman kokemuksensa ja aiemman talouskeskustelun valossa. Eräs haasteltava pohtii, että kysymystä siitä, kuulostavatko asiantuntijan näkemykset uskottavilta, on pakko "heijastaa siihen omaan aikaisempaan tietoon". Toinen miettii kysymystä uskottavan asiantuntijan tunnistamisesta samansuuntaisesti:

[E]ihän sitä heti huomaa, että joku sanoo jotain tosi fiksulta kuulostavaa, niin vaikea sitä [on arvioida], jos sulla ei oo aiempaa kokemusta. Ja ei toimittajalla kuulukaan olla sellaista tietämystä, että se pystyis heti arvioimaan sitä, kuinka todellisuudessa loppuun mietittyä asiantuntijuutta se on. Ehkä sen huomaa vasta sitten ajan kuluessa, että oppii arvostamaan tiettyjä asiantuntijoita vähän enemmän kuin toisia. (Toimittaja 16.)

Haastatteluiden perusteella suomalaisia talousasiantuntijoita pidetään yleisesti uskottavina. Talousasiantuntijuutta ei kuitenkaan pidetä täysin puolueettomana tiedontuotannon kenttänä. Toimittajat arvioivat kriittisesti ajatusta siitä, että asiantuntijat kanavoisivat julkiseen keskusteluun pelkästään objektiivisia taloustieteellisiä totuuksia. Toimittaja pohtii, että talouden asiantuntijat voivat painottaa julkisuudessa erilaisia asioita: 
Mä viittasinkin tähän, että meillä on jotain kollegoita, jotka ajattelee, että jos joku on tittelillä professori, se tekee objektiivista tiedettä, joten hän on puolueeton. Mutta mä itse en usko sitä näkökantaa, vaan mä ajattelen, että nimenomaan erityisesti kun on kyseessä kansantaloustiede tai niin kuin [...]. Talouspolitiikan asiantuntijoiden taustalla on aina ne melkein ne [...] Siinä on aina ne semmoiset tavallaan lähtökohtaoletukset aina [...]. (Toimittaja 1.)

Eläköitynyt toimittaja kertoo haastattelussa, että kaikilla asiantuntijoilla on "painotus johonkin suuntaan", vaikka miettiikin samalla, että esimerkiksi yliopistotutkijoilla ei ole niin selkeästi "työnantajan pakkopaitaa" päällä kuin muilla talouden asiantuntijoilla. Talouslehden toimittaja kritisoi niin ikään ajatusta puolueettomasta asiantuntijuudesta sanoessaan, että "ekonomistit tykkää[vät] esiintyä luonnontieteilijöinä", vaikka ovatkin todellisuudessa yhteiskuntatieteilijöitä. Puoluelehden toimittaja kertoo miettineensä, onko taloustiede "mitään oikeaa tiedettä ollenkaan", kun saman koulutuksen saaneet ekonomistit ovat asioista niin erimielisiä. Yksi journalisti puolestaan hämmästelee taloustieteen olevan "erikoinen tiede":

[J]os mennään ihan tonne professoripuolelle taloustieteilijöihin, niin [...] siellähän tulee niin kuin jopa ihan päinvastaisia selityksiä ja näkemyksiä, että monta kertaa mä olen miettinyt sitä [...] että kyllä toi taloustiede, niin kyllähän se aika erikoinen tiede on, [...] että ei se ole mikään luonnontiede, että kansantaloustiede on vahvasti politiikkaa, ja se kyllä sitten näkyy. Mutta se on hyvä tunnistaa ja tavallaan, että ei sitä vertaa silleen, että [...] metrin mitastahan me ei voida kiistellä, että se on se metri, mutta sitten kun tullaan taloustieteen puolelle, niin asiat eivät ole niin yksinkertaiset. Mutta tää on niin kuin hyvä ehkä laajastikin sekä toimittajien ja yleisön ymmärtää, että sinne mahtuu hyvin paljon erilaisia näkemyksiä. (Toimittaja 11.)

Asiantuntijatiedon ja vaikuttamispyrkimysten välinen raja vaikuttaa haastattelumateriaalin perusteella häilyvältä. Vaikka journalismissa tarvitaan uskottavaa asiantuntijuutta, journalistit suhtautuvat kriittisesti ajatukseen taloudellisen asiantuntijatiedon arvovapaudesta ja puolueettomuudesta (ks. Fenton ym. 1997, 3). Tämä ei tarkoita, että journalistit tarkastelisivat asiantuntijoita yksinkertaisesti joidenkin eturyhmien käsikassaroina: kyse on pikemminkin siitä, että politiikan ja asiantuntijatiedon väliset rajanvedot ovat epäselviä erityisesti talouspolitiikan kysymyksissä (vrt. Doyle 2006, 443-444). Havainto tukeekin tuloksia, joiden mukaan tieteen ja vaikuttamispyrkimysten väliset rajat sumenevat myös julkisuudessa erilaisten intressiryhmien vedotessa tutkitun tiedon arvovaltaan (Laursen ja Trapp 2019, 14-15).

\section{Yhteenveto ja päätelmät}

Tarkastelin tässä artikkelissa 19 toimittajahaastattelun ja kyselytutkimusaineiston $(\mathrm{N}=42)$ avulla, miten suomalaiset talous- ja politiikan toimittajat arvioivat erilaisten talouden asiantuntijaryhmien uskottavuutta ja miten uskottava talouden asiantuntijuus rakentuu journalistin silmissä. Artikkelin lähtökohtana oli, että taloutta koskevaa julkista keskustelua rakentava ja välittävä journalismi tarvitsee uskottaviksi koettuja asiantuntijoita luodak- 
seen faktapohjaisia esityksiä talouden ja talouspolitiikan ilmiöistä. Journalismissa taajaan esiintyvät ja erilaisia instituutioita, kuten taloustieteellisiä tutkimuslaitoksia, pankkeja ja valtionhallinnon instituutioita, edustavat talouden asiantuntijat ovat auktoriteetteja, jotka arvioivat tehdyn talouspolitiikan mielekkyyttä ja talouspolitiikan liikkumatilaa (Berry 2016; Chadwick ym. 2020). Näin myös journalismin tutkimuksessa on syytä kiinnittää huomiota siihen, miten taloutta ja politiikkaa työkseen seuraavat toimittajat arvioivat erilaisten talouden asiantuntijoiden arvovaltaa ja uskottavuutta ja miten näkemys uskottavasta asiantuntijasta rakentuu journalistin silmissä.

Artikkelin empiirisen analyysin teoreettisena pohjana toimi uskottavuuden hierarkian käsite (Becker 1967). Journalistien, joiden työtä ohjaavat toisaalta ammatin jokapäiväiset käytännöt ja vaatimukset ja toisaalta tarve pysytellä journalististen ammattinormien puitteissa, on arvioitava rutiininomaisesti erilaisten uutislähteiden uskottavuutta. Lisäksi journalismi tarvitsee puolueetonta asiantuntijatietoa oman objektiivisuutensa tueksi (Albæk 2011; Boyce 2006). Näin ollen journalismiin muotoutuu uskottavuuden hierarkia, jonka huipulla ovat paitsi demokraattisesti valitut poliittiset päättäjät ja yhteiskunnan muut eliittiryhmät myös asiantuntijat, jotka pystyvät tuottamaan puolueetonta tietoa journalismin käyttöön. Marginaalisemmiksi koetut poliittiset toimijat samoin kuin asiantuntijat, joiden voi katsoa pyrkivän ajamaan jonkin yhteisön intressejä, ovat uskottavuuden hierarkiassa alempana (Hall ym. 1978, 58; Laursen ja Trapp 2019, 3-5; Miller ja Williams 1998, 126). Valtavirtainen journalismi kuvaakin politiikkaa usein erilaisten eliittiryhmien näkökulmasta ja niiden välisenä kamppailuna (Hallin 1984; Bennett 1990).

Väitin artikkelissa kyselytutkimukseen ja haastatteluaineistoon nojaten, että taloutta ja politiikkaa työssään seuraavien toimittajien silmissä talouden asiantuntijat asettuvat selvästi uskottavuuden hierarkiaan, jonka ylätasot on varattu taloudellisten tutkimuslaitosten (kuten Elinkeinoelämän tutkimuslaitoksen Etlan ja Palkansaajien tutkimuslaitoksen PT:n) sekä valtionhallinnon instituutioiden (kuten Suomen Pankin ja valtiovarainministeriön) asiantuntijoille. Journalistien suhtautuminen esimerkiksi yksityisten pankkien asiantuntemukseen on puolestaan epäilevämpää. Asiantuntijoiden asema uskottavuuden hierarkiassa heijastelee odotetusti heidän institutionaalista asemaansa: tutkimuslaitokset ja julkisen sektorin instituutiot näyttäytyvät uskottavampina asiantuntijainstituutioina kuin yksityiset pankit. Pankkien kohdalla journalistien suhtautuminen asiantuntijoiden mahdollisiin taustavaikuttumiin on kriittisempää. Vaikka artikkelin tuloksista ilmeneekin, että uskottavan asiantuntijuuden ehtona on asiantuntijan institutionaalinen asema, ei kysymystä asiantuntijan uskottavuudesta toisaalta tule palauttaa yksin teknisiin seikkoihin. Haastatteluiden perusteella voi arvioida, että uskottavalla asiantuntijalla on myös henkilökohtaista "mediapääomaa" (Davis ja Seymour 2010, 742-743): uskottava asiantuntija on entuudestaan tuttu julkisuudesta, ja toimittajat ovat oppineet luottamaan hänen arvioihinsa.

Haastatellut toimittajat kertoivat pitävänsä Elinkeinoelämän tutkimuslaitoksen Etlan ja Palkansaajien tutkimuslaitoksen PT:n asiantuntijoita uskottavina. Toimittajat pitivät haastatteluissa taajaan esillä sitä, että laitosten toimintaa rahoittavat suomalainen liike-elämä ja ammattiyhdistysliike. Tästä huolimatta tutkimuslaitoksissa työskenteleviä asiantuntijoita pidettiin itsenäisinä tieteenteon ammattilaisina. Toimittajat pitivät myös valtiovarainministeriötä ja Suomen Pankkia uskottavina, vaikka niiden vahvaa asemaa suomalaisen talouspolitiikan valmistelussa ja talouspolitiikkaa koskevassa julkisessa keskustelussa arvioitiin 
myös kriittisesti. Toimittajat pohtivat, olisiko journalismissa syytä haastaa erityisesti valtiovarainministeriön arvovaltaa nykyistä ärhäkämmin. Samalla ministeriön saamaa näkyvyyttä pidettiin perusteltuna: ministeriön rooli talouspolitiikkaa koskevan tiedon lähteenä, ennusteiden laatijana ja talouspolitiikan käytännön valmistelijana on niin merkittävä, että journalistien on syytä seurata ministeriötä tarkasti. Valtiovarainministeriön asemaa uskottavuuden hierarkiassa tukee sen vahva institutionaalinen asema talouspoliittisen vallan käyttäjänä (vrt. Hall ym. 1978, 58).

Niin kyselytutkimuksen kuin haastatteluaineistonkin perusteella toimittajat suhtautuivat pankkien taloudelliseen asiantuntemukseen epäilevämmin kuin edellä mainittuihin asiantuntijatahoihin. Pankit ja niissä työskentelevät asiantuntijat ovat taloutta ja markkinoita seuraavia ammattilaisia ja näin ollen hyödyllisiä ja jopa korvaamattomia asiantuntijuuden lähteitä, mutta niiden uskottavuutta nakertaa journalismiin kiinteästi kuuluva lähdekritiikki ja lähteiden motiivien epäily (ks. Reich 2011,19 ). Journalismin näkökulmasta pankkeihin on suhtauduttava epäilevämmin kuin tutkimuslaitoksiin tai valtionhallinnon organisaatioihin. Kiinnostavaa kyllä journalistien näkemykset poikkeavat pankeissa työskentelevien ekonomistien näkemyksistä: pankkiekonomistit ovat päinvastoin korostaneet, että he esiintyvät julkisuudessa riippumattomina talouden analyytikkoina (Simola ja Reunanen 2010, 147149).

Siitä huolimatta, että asiantuntijoiden uskottavuudessa on selkeitä eroja, haastatellut toimittajat suhtautuivat kriittisesti ajatukseen taloutta koskevan tiedon puolueettomuudesta. Toimittajat päinvastoin pohtivat, että talouspolitiikan kysymyksissä tiede ja politiikka nivoutuvat tiiviisti yhteen ja että ajatus täysin puolueettomasta asiantuntijasta on utopia. Vaikka asiantuntijoita ei pidettäisikään tietyn eturyhmän selvinä puolestapuhujina, talouspolitiikan erimielisyydet niveltyvät selvästi myös taloustiedettä ja asiantuntijatietoa koskeviin ristiriitoihin. Tulokset voivat kieliä ensinnäkin siitä, että finanssi- ja eurokriisin jälkeen on keskustelu kiivaasti taloustieteen ja vaikutusvaltaisten asiantuntijoiden roolista talouskuripolitiikan oikeuttamisessa (ks. Blyth 2015). Toiseksi havainnot voivat kertoa myös siitä, että moninaisten etu- ja intressiryhmien tapa nojata julkisessa toiminnassaan tutkittuun tietoon sumentaa asiantuntijuuden ja politiikan välisiä rajoja myös journalismissa (vrt. Laursen ja Trapp 2019).

Tällä artikkelilla on puutteensa ja rajoituksensa. Suomalaiselle journalismille on ominaista vahva kiinnittyminen puolueettomuuden kaltaisiin länsimaisen journalismin ydinarvoihin (Pöyhtäri, Väliverronen ja Ahva 2016, 12), ja voi olla, että erilaisissa mediajärjestelmissä (ks. Hallin ja Mancini 2004) toimivat journalistit arvioivat myös asiantuntijuuden uskottavuuden hierarkiaa eri tavoin. Tämän artikkelin analyysiosiossa ei ole myöskään tehty eroa tarkemmin talouteen erikoistuvien medioiden ja yleismedioiden välille, vaikka niiden tavassa käsitellä talouspolitiikan ilmiöitä on jonkin verran eroja (Árrese ja Vara 2015).

Kyselytutkimuksen osalta aineisto on valitettavan pieni, minkä vuoksi olisi tärkeää tarkastella journalismin, talouden ja asiantuntijuuden kysymyksiä suuremmilla määrällisillä aineistoilla kuin tässä artikkelissa. Myös erilaisille laadullisille tulokulmille on kysyntää, kun koronapandemia ja sen taloudellisia vaikutuksia pehmentävä elvytyspolitiikka eittämättä kiihdyttävät myös talouspolitiikan suunnasta käytävää keskustelua. Talouden asiantuntijat, jotka ovat jo 1900-luvun puolivälistä lähtien olleet merkittäviä talouspoliittisten ideoiden tuottajia ja mielipidevaikuttajia (Mudge 2018), tulevat varmasti olemaan talouspolitiikan 
journalismin ytimessä, kun välittömän kriisin jälkeisen politiikan suuntaviivoja hahmotellaan.

Toisaalta on perusteltua kysyä, miten tarkasti uskottavuuden hierarkian käsite ja sen instituutiokeskeinen näkökulma kuvaavat journalismin ja asiantuntijuuden välistä suhdetta aikana, jona journalismin perinteinen portinvartija-asema on heikentynyt ja sosiaalisesta mediasta on tullut keskeinen julkisen debatin areena (Chadwick 2013). Sosiaalinen media ja siellä nopeastikin rakentuvat asiantuntijaverkostot mahdollistavat perinteisen asiantuntijuuden haastamisen (Väliverronen ym. 2020). Tämän artikkelin ilmeisenä heikkoutena voi pitää asiantuntijuuden uudenlaisten muotojen sivuuttamista. Vastaisuudessa olisi kiinnostavaa pohtia muun muassa sitä, millaisena talouden asiantuntijuuden kasvualustana erilaiset sosiaalisen median alustat, kuten toimittajienkin tarkoin seuraama Twitter (ks. Harjuniemi 2020, 64-65), toimivat ja millainen on sosiaalisen median suhde asiantuntijoiden uskottavuuteen.

Tämän artikkelin puutteiden joukkoon lienee syytä lisätä sekin, että artikkeli sivuuttaa kysymyksen siitä, missä määrin journalismin suhde asiantuntijoihin ja muihin auktoriteetteihin on muuttunut viimeisten vuosikymmenten aikana. Moni tutkija on väittänyt, että länsimaisen journalismin suhde vallanpitäjiin alkoi muuttua entistä kriittisemmäksi 1900luvun viimeisten vuosikymmenten aikana. (esim. Kantola 2013). On myös esitetty, että journalismista on tullut aiempaa tulkitsevampaa (Esser ja Umbricht 2014). Nykyjournalisti uskaltaa ottaa itsekin analyytikon tai asiantuntijan roolin (Lundell ja Ekström 2013; Reunanen ja Koljonen 2014, 26-44). Toisaalta vakiintuneilla asiantuntijoilla vaikuttaa edelleen olevan vahva rooli talouspolitiikkaa koskevassa julkisessa keskustelussa. Näin ollen instituutioiden arvovaltaa korostavia näkemyksiä ei ole - mediaympäristön toimintalogiikan kiistattomista muutoksista huolimatta - syytä hylätä.

\section{Viitteet}

Vastaajista tarkemmin Harjuniemi 2020. 19-22.

\section{Kirjallisuus}

Albæk, Erik, Peter Munk Christiansen ja Lise Togeby. 2003. "Experts in the mass media: Researchers as Sources in Danish Daily Newspapers, 1961-2001. Journalism Q Mass Communication Quarterly 80 (4): 937-948. https://doi.org/10.1177/107769900308000412.

Albæk, Erik. 2011. "The interaction between experts and journalists in news journalism." Journalism 12 (3): 335348. https://doi.org/10.1177/1464884910392851.

Árrese, Angel ja Alfonso Vara. 2015. "Divergent Perspectives? Financial Newspapers and the General Interest Press." Teoksessa The Euro Crisis in the Media. Journalistic Coverage of Economic Crisis and European Institutions, toimittanut Robert G. Pickard, 149-176. Lontoo: I.B. Tauris.

Basu, Laura. 2019. " Living within our means: The UK news construction of the austerity frame over time." Journalism 20 (2): 313-330. https://doi.org/10.1177/1464884917708870.

Becker, Howard S. 1967. “Whose side are we on?” Social Problems 14 (3): 239-247. https://doi.org/10.2307/799147.

Bennett, Lance. 1990. "Toward a theory of press-state relationship in the United States." Journal of Communication 15 (2), 103-127. https://doi.org/10.1111/j.146o-2466.199o.tbo2265.x.

Berkowitz, Daniel. 2008. "Reporters and their sources." Teoksessa The Handbook of Journalism Studies, toimittaneet Karin Wahl-Jorgensen ja Thomas Hanitzsch, 102-115. Abingdon: Routledge. 
Berry, Mike. 2016. "No alternative to austerity: How BBC broadcast news reported the deficit debate." Media, Culture Q Society 38 (6): 844-863. https://doi.org/10.1177/0163443715620931.

Berry, Mike. 2019. The Media, the Public and the Great Financial Crisis. Cham: Palgrave Macmillan.

Blyth, Mark. 2015 Austerity: The History of a Dangerous Idea. New York: Oxford University Press.

Boyce, Tammy. 2006. “Journalism and expertise." Journalism Studies 7(6): 889-906. https://doi.org/10.1080/14616700600980652.

Cawley, Anthony. 2016. "From AAA to junk: Credit rating agencies as news sources in the Irish print-media during the economic crisis, 2008-2013." Journalism Studies 17 (5): 647-666. https://doi.org/10.1080/1461670X.2015.1006901.

Chadwick, Andrew. 2013. The Hybrid Media System. Politics and Power. Oxford: Oxford University Press.

Chadwick, Andrew, Declan McDowell-Naylor, Amy P. Smith ja Ellen Watts. 2020. "Authority signaling: How relational interactions between journalists and politicians create primary definers in UK broadcast news." Journalism 21 (7): 896-914. https://doi.org/10.1177/1464884918762848.

Davis, Aeron ja Emily Seymour. 2010. "Generating forms of media capilta inside and outside a field: The strange case of David Cameron in the UK political field." Media, Culture Q Society 32 (5): 739-759. https://doi.org/10.1177/0163443710373951.

Davis, Aeron. 2018. “Whose economy, whose news?" Teoksessa Media and Austerity: Comparative Perspectives, toimittaneet Laura Basu, Steve Schifferes ja Sophie Knowles, 157-170. London: Routledge.

Deacon, David ja Peter Golding. 1994. Taxation and Representation: The Media, Political Communication and the Poll Tax. Lontoo: John Libbey \& Company.

Deuze, Mark. 2005. "What is journalism: professional identity and ideology of journalists reconsidered." Journalism 6 (4): 442-464. https://doi.org/10.1177/1464884905056815.

Dimitrova, Daniel V. ja Jesper Strömbäck. 2009. "Look who's talking: Use of sources in newspaper coverage in Sweden and the United States.” Journalism Practice 3(1): 75-91. https://doi.org/10.1080/17512780802560773.

Doudaki, Vaia, Angeliki Boubouka ja Christos Tzalavras. 2019. "Framing the Cypriot economic crisis: in the Service of the neoliberal vision." Journalism 20 (2): 349-368. https://doi.org/10.1177/1464884916663601.

Doyle, Gillian. 2006. "Financial news journalism: a post-Enron analysis of approaches towards economic and financial news production in the UK." Journalism 7 (4): 433-452. https://doi.org/10.1177/1464884906068361.

Earle, Joe, Cahal Moran ja Zach Ward-Perkins. 2017. The Econocracy: The Perils of Leaving Economics to the Experts. Manchester: Manchester University Press.

Esser, Frank ja Andres Umbricht. 2014. "The evolution of objective and interpretative journalism in the Western press: Comparing six news systems since the 1960s." Journalism Q Mass Communication Quarterly 91 (2): 229-249. https://doi.org/10.1177/1077699014527459.

Eva. 2020. Elinkeinoelämän valtuuskunta Eva. Luettu 19.1.2021. https://www.eva.fi/julkaisut/.

Fenton, Natalie, Alan Bryman, David Deacon ja Peter Birmingham. "'Sod off and fin dus a boffin': journalists and the social science conference." Sociological Review 45 (1): 1-23. https://doi.org/10.1111/1467-954X.00051.

Hall, Stuart, Chas Critcher, Tony Jefferson, John Clarke ja Brian Roberts. 1978. Policing the Crisis: Mugging, the State, and Law and Order. Lontoo: Macmillan.

Hallin, Daniel C. 1984. "The media, the war in Vietnam, and political support: A critique of the thesis of an oppositional media." The Journal of Politics 46(1): 2-24. https://doi.org/10.2307/2130432.

Hallin, Daniel ja Paolo Mancini. 2004 Comparing media systems. Three models of media and politics. Cambridge: Cambridge University Press.

Hansen, Anders. 1994. "Journalistic practices and science reporting in the British Press." Public Understanding of Science 3 (2): 111-134. https://doi.org/10.1088/0963-6625/3/2/001.

Harjuniemi, Timo, Juha Herkman ja Markus Ojala. 2015. "Eurokriisin politisoituminen suomalaisissa sanomalehdissä." Media Q viestintä 38 (1): 1-22. https://doi.org/10.23983/mv.6210o.

Harjuniemi, Timo ja Marko Ampuja. 2019. "Established ideas from established institutions: Austerity and structural reforms in the Finnish economic policy debate." Critical Policy Studies 13 (4): 451-469. https://doi.org/10.1080/19460171.2018.1451758.

Harjuniemi, Timo. 2020. Asiantuntijoita vai asiansa ajajia? Suomalaisten toimittajien näkemyksiä talouspolitiikan asiantuntijuudesta. Helsinki: Helsingin yliopisto.

Hurmeranta, Markku. 2009. Talousmedia ja valkokaulustyöläiset. Ydinkohderyhmän arvioita talousjournalismin tasosta ja verkkomedian roolista. Tampere: Tampereen yliopisto.

Jacobsson, Diana. 2018. "Business elite competition or a common concern?" Journalism Studies 19 (1): 105-125. https://doi.org/10.1080/1461670X.2016.1164615. 
Kantola, Anu. 2013. "From gardeners to revolutionaries: The rise of the liquid ethos in political journalism. Journalism 14 (5): 606-626. https://doi.org/10.1177/1464884912454504.

Kantola, Anu ja Johannes Kananen. 2013. "Seize the moment: Financial crisis and the making of the Finnish competition state." New Political Economy 18 (6): 811-826. https://doi.org/10.1080/13563467.2012.753044.

Laursen, Bo ja Leila Trapp. 2019. "Experts or advocates: Shifting roles of central sources used by journalists in news stories?" Journalism Practice 15 (1): 1-18. https://doi.org/10.1080/17512786.2019.1695537.

Lindén, Carl-Gustav. 2012. National Champions in Combat. Nokia, Ericsson and the Sensemaking of Business News. Helsinki: Helsinki University Press.

Lundell, Åsa Kroon ja Mats Ekström. 2013. "Interpreting the news: Swedish correspondents as expert sources." Journalism Practice 7 (4): 517-532. https://doi.org/10.1080/17512786.2013.802490

Manning, Paul. 2001. News and news sources: A critical introduction. Lontoo: Sage.

McNair, Brian. 2008. “Journalism and democracy." Teoksessa The Handbook of Journalism Studies, toimittaneet Karin Wahl-Jorgensen ja Thomas Hanitszh, 237-249. New York: Routledge.

Miller, David ja Kevin Williams. 1998. "Sourcing AIDS News.” Teoksessa The Circuit of Mass Communication: Media Strategies, Representation and Audience Reception in the AIDS Crisis, toimittaneet David Miller, Jenny Kitzinger, Kevin Williams ja Peter Beharrell, 123-146. Lontoo: Sage.

Mudge, Stephanie L. 2018. Leftism Reinvented: Western Parties from Socialism to Neoliberalism. Cambridge, Mass.; Harvard University Press.

Mylonas, Yiannis. 2014 "Crisis, austerity and opposition in mainstream media discourses of Greece." Critical Discourse Studies 11 (3): 305-321. https://doi.org/10.1080/17405904.2014.915862.

Ojala, Markus. 2017. The Making of Global Elite: Global Economy and the Davos Man in Financial Times 2001-2011. Helsinki: Unigrafia.

Pajari, Elina. 2003. "Arveluttava analyytikko talousjournalistien rutiinilähteenä." Teoksessa Journalismikritiikin vuosikirja 2003, toimittanut Pertti Vehkalahti, 183-186. Tampere: Tampereen yliopisto, Journalismin tutkimusyksikkö.

Parviainen, Aapo. 2014. "Mediassa paras ekonomisti on pankkiekonomisti." Kansantaloudellinen aikakauskirja 110 (4): 574-581.

Pedroso Neto, Antonio ja Tomás Undurraga. 2018. "The elective affinity between elite journalists and mainstream economists in Brazil." Journalism Studies 19 (15): 2243-63. https://doi.org/10.1080/1461670X.2017.1334572.

Pekkarinen, Jukka. 1989. "Keynesianism and the Scandinavian Models of Economic Policy." Teoksessa The Political Power of Economic Ideas. Keynesianism Across Nations, toimittanut Peter A. Hall, 311-347. Princeton: Princeton University Press.

Pekkarinen, Jukka ja Visa Heinonen. 1998. “Talouspolitiikka ja kansantaloustieteellinen asiantuntemus Suomessa." Teoksessa Asiantuntemuksen politiikka: Professiot ja julkinen valta Suomessa, toimittaneet Ilpo Koskinen ja Juri Mykkänen, 84-100. Helsinki: Helsinki University Press.

Pennanen, Risto ja Martti Ristimäki. 2003. "Lähteet kertovat, toimittaja Palmu." Teoksessa Journalismikritiikin vuosikirja 2003, toimittanut Pertti Vehkalahti, 177-182. Tampere: Tampereen yliopisto, Journalismin tutkimusyksikkö.

Philo, Greg. 1995. “Audience beliefs and the 1984/5 miners' strike.” Teoksessa Glasgow Media Group Reader, Volume 2. Industry, Economy, War and Politics, toimittanut Greg Philo, 37-42. Lontoo: Routledge.

Politiikan toimittajat. 2020. Politiikan toimittaja ry. Luettu 19.1.2021. https://www.politiikantoimittajat.fi/yhdistys/.

Pöyhtäri, Reeta, Jari Väliverronen ja Laura Ahva. 2016. "Suomalaisen journalistin itseymmärrys muutosten keskellä." Media Q viestintä 39 (1): 1-23. https://doi.org/10.23983/mv.61434.

Railo, Erkka ja Sini Ruohonen. 2016. "Vaalikampanjat ja julkisuuden agenda." Teoksessa Poliittisen osallistumisen eriytyminen. Eduskuntavaalitutkimus 2015, toimittaneet Kimmo Grönlund ja Hanna Wass, 76-94. Oikeusministeriö.

Reich, Zvi. 2011. "Source credibility as a journalistic work tool." Teoksessa Journalists, Sources, and Credibility, toimittaneet Bob Franklin ja Matt Carlson, 19-36. Lontoo: Routledge.

Reunanen, Esa ja Kari Koljonen. 2014. Toimittajan sanansijat. Tampere: Tampere University Press.

Sanders, David ja Neil Gavin. 2004. "Television news, economic perceptions and political preferences in Britain, 1997-2001." The Journal of Politics 66 (4): 1245-1266. https://doi.org/10.1111/j.0022-3816.2004.00298.x.

Schudson, Michael. 2006. "The trouble with experts - and why democracies need them." Theory and Society 35 (5/6): 491-506. https://www.jstor.org/stable/4501762.

Simola, Anna ja Esa Reunanen. 2010. Kaikki toistaiseksi hyvin. Kansainvälinen finanssikriisi talousjournalismissa. Tampere: Tampereen yliopisto, Journalismin tutkimusyksikkö. 
Steele, Janet E. 1995. "Experts and the operational bias of television news: the case of the Persian Gulf War." Journalism Q Mass Communication Quarterly 72 (4): 799-812. https://doi.org/10.1177/107769909507200404.

Taloustoimittajat. 2020. Taloustoimittajat ry. Luettu 19.1.2021. https://taloustoimittajat.fi/.

Tracy, James F. 2012. “Covering 'financial terrorism'.” Journalism Practice 6 (4): 513-529. https://doi.org/10.1080/17512786.2011.633789.

Uusitalo, Roope. 2011. "Suomalaisekonomistit mediassa." Kansantaloudellinen aikakauskirja 107 (3): 341-349.

Vaara, Eero. 2014 "Struggles over legitimacy in the Eurozone crisis: Discursive legitimation strategies and their ideological underpinnings." Discourse Q Society 25 (4): 500-518. https://doi.org/10.1177/o957926514536962.

Walsh, Catherine. 2021. "Constructing experts without expertise. Fiscal reporting in the British press, 2010-2016." Journalism Studies 21 (15): 2059-77. https://doi.org/10.1080/1461670X.2020.1809496.

Weible, Christopher M. 2008. "Expert-based information and policy subsystems: A review and synthesis. The Policy Studies Journal 36 (4): 615-635. https://doi.org/10.1111/j.1541-0072.2008.00287.x.

Weingart, Peter. 1999. "Scientific expertise and political accountability: paradoxes of science in politics." Science and Public Policy 26(3): 151-161. https://doi.org/10.3152/147154399781782437.

Volkmer, Ingrid ja Amira Firdaus. 2012. "Between networks and 'hierarchies of credibility': Navigating journalistic practice in a sea of user-generated content." Teoksessa Rethinking Journalism: Trust and Participation in a Transformed News Landscape, toimittaneet Chris Peters ja Marcel J. Broersma, 101-113. Lontoo: Routledge.

Wren-Lewis, Simon. 2018. "'Mediamacro': Why the news media ignores economic experts." Teoksessa Media and Austerity: Comparative Perspectives, toimittaneet Laura Basu, Steve Schifferes ja Sophie Knowles, 170-182. New York: Routledge.

Wuokko, Maiju. 2017. "Business in the battle of ideas, 1945-1991: Conclusions from the Finnish case." Scandinavian Economic History Review 65 (3): 279-293. https://doi.org/10.1080/03585522.2017.1371638.

Väliverronen, Esa, Salla-Maaria Laaksonen, Mikko Jauho ja Piia Jallinoja. 2020. "Liberalists and data-solutionists: Redefining expertise in Twitter debates on coronavirus in Finland." Journal of Science Communication 19 (5): 1-21. https://doi.org/10.22323/2.19050210.

Yrjänä, Jouni. 2018. Rahan perässä, vallan kintereillä. Suomalaisen talousjournalismin historia. Helsinki: Otava. 